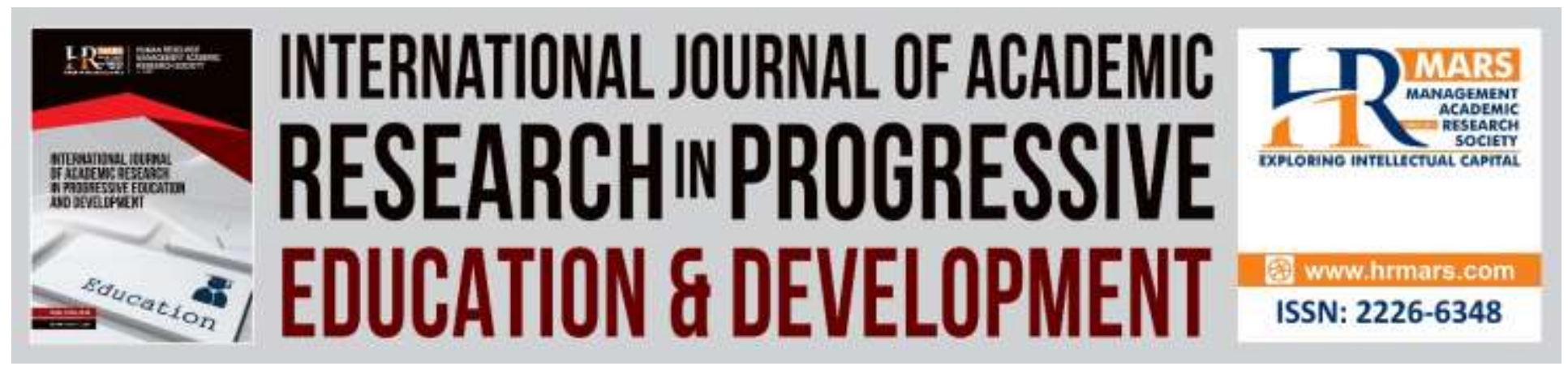

\title{
Issue of Fairness in Benchmarking Teacher Quality in Malaysia Teaching Standard: Lessons for Other Countries
}

\author{
Nur Surayyah Madhubala Abdullah
}

To Link this Article: http://dx.doi.org/10.6007/IJARPED/v8-i4/6694

DOI:10.6007/IJARPED/v8-i4/6694

Received: 15 October 2019, Revised: 30 October 2019, Accepted: 11 November 2019

Published Online: 30 November 2019

In-Text Citation: (Abdullah, 2019)

To Cite this Article: Abdullah, N. S. M. (2019). Issue of Fairness in Benchmarking Teacher Quality in Malaysia Teaching Standard: Lessons for Other Countries. International Journal of Academic Research in Progressive Education and Development, 8(4), 705-712.

Copyright: (C) 2019 The Author(s)

Published by Human Resource Management Academic Research Society (www.hrmars.com)

This article is published under the Creative Commons Attribution (CC BY 4.0) license. Anyone may reproduce, distribute, translate and create derivative works of this article (for both commercial and non-commercial purposes), subject to full attribution to the original publication and authors. The full terms of this license may be seen at: http://creativecommons.org/licences/by/4.0/legalcode

Vol. 8(4) 2019, Pg. 705 - 712

http://hrmars.com/index.php/pages/detail/IJARPED JOURNAL HOMEPAGE

Full Terms \& Conditions of access and use can be found at http://hrmars.com/index.php/pages/detail/publication-ethics 


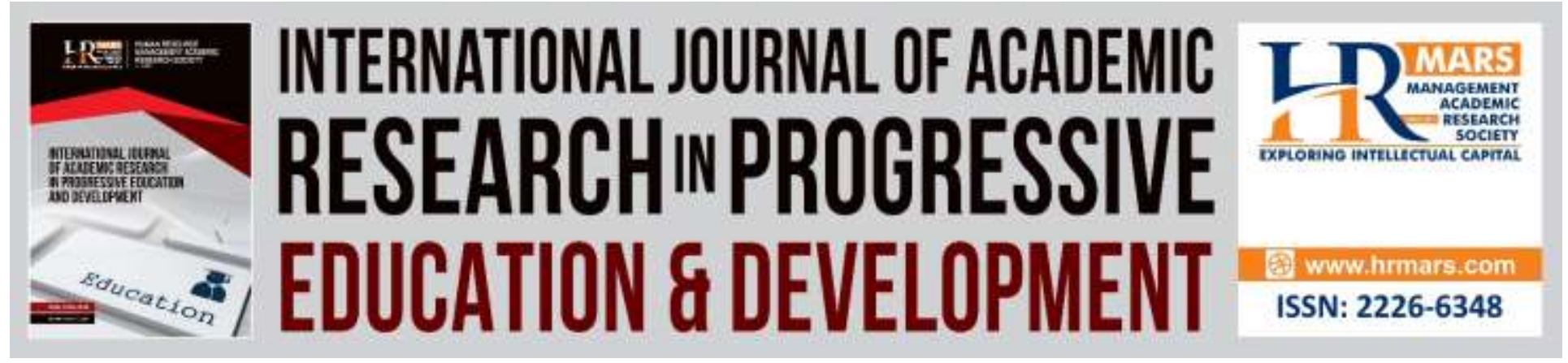

\title{
Issue of Fairness in Benchmarking Teacher Quality in Malaysia Teaching Standard: Lessons for Other Countries
}

\author{
Nur Surayyah Madhubala Abdullah \\ Department of Language and Humanities Education, Faculty of Educational Studies, Putra \\ University Malaysia, 43400 Serdang, Selangor.
}

\begin{abstract}
The issue of fairness in the use of student achievement in benchmarking teacher standard and hence, as a measure of teacher quality in Malaysian Teaching Standards (MTS) is highlighted. Through an examination of the idea of teacher standards in MTS and consideration of the issue of what should be an adequate measure of teacher performance, two observations are made. First, the use of student achievement to measure teacher standard and, hence their quality as teachers, raises an issue of fairness in the assessment of teacher performance. Second, setting a standard of producing an ideal person in MTS renders the standards questionable as a fair measure of teacher performance, considering the complexity of teaching and, learner diversity. Together the findings reveal two issue. First, what should be used to gauge teacher quality? Second, how should teacher quality be understood? Several possible implications for improving teacher quality within policy and teacher education programs are noted. Standards should be couched in reality of teachers and teaching to avoid unfair treatment of teachers. The paper offers policy makers, practitioners and teacher educators in other countries a brief overview of some challenges of ensuring policy or programs on teacher standards are socially just.

Keywords: Teacher Standard, Teacher Quality, Teachers' Professional Development, Malaysia

\section{Introduction}

The notion of teaching standards has become a buzz word in teacher education today. In the Malaysian context, Malaysian Teacher Standards (MTS) refers to qualities of teachers, and further teacher education program that benchmark standards within teacher education, and teaching profession in a Malaysia against global teacher education standards. The aim: to ensure that teaching and learning in Malaysia can be compared on a similar basis with that of another country. Further to that, it serves as a basis for potential international students to assess the quality of education in Malaysia. Therefore, the MTS is seen not only as a measure of a teacher but on a much broader scale the achievement of a Malaysia particularly in education vis a vis its development as a nation.
\end{abstract}


Historically, the MTS was launched in 2009. As a policy document it is central to achieving the aim of the Malaysian National Education Blueprint 2013-2025 (2013). However, it should be recognized that the drive towards improving teacher quality and education standards is not a new policy. Throughout the Malaysian Education Act 1996, and later the Education Development Plan 2006-2010, the aim of the Ministry of Education has been to improve education standards in Malaysia. Teacher excellence has always been at the center of this drive. Indeed, the move to introduce the Malaysian Teaching Standards by the Ministry of Education of Malaysia in 2009 was in line with meeting the goal of the country of being a developed country with first class education to meet the needs of a global society (Bernama, 2009; Istrate, 2018).

Briefly, "MTS serves as a guideline for teachers to develop professional values, knowledge and understanding while acquiring the relevant skills in teaching" (Chapman 2009, para 2.). Specifically, it is a guideline to measure teachers' practice. It is rigorous and is set beyond the minimum requirements of teaching. It serves as an early 'warning system' so that teachers themselves are sensitive to the need to undertake the strengthening, improvement and enhancement of knowledge, skills and personality (Goh, 2011). It outlines the professional competency that should be achieved by teachers, and the requirements that should be provided by agencies and teacher training institutions to help teachers in achieving the desired level of competency (p. 3). In this context, the desired level of competencies is measured on the basis of the outcome seen in the ideal student model.

Hence, MTS is a measure of teaching excellence used by the Ministry of Education Malaysia to evaluate teachers towards improving the quality of education; as a basis for teachers to evaluate themselves towards improving their teaching; and for teacher educators as a basis of measuring their programs including courses and other aspects of their teaching program towards offering quality teacher training and producing quality teachers and; as a guide and reference for administrators, managers, teacher training institutions and agencies in Malaysia to judge their performances towards ensuring that the ideal student model is achieved by teachers However, the question remains how far is this policy document a fair judge of teacher quality? Specifically, the concern lies in the idea that the student's achievement is the measure of that quality. The presence of the ideal student in the notion of teacher standard and quality renders the policy problematic because of the questions it raises. One of which forms the focus of this paper that is, whether it is fair for the standard and quality of teachers to be framed in student quality?

Interestingly, one study (Mansor, Fisher, Rasul, Ibrahim and Yusoff, 2012), suggests that Malaysian teachers, instead of evolving with the imposition of standards, are "dissolving" it ( $p$. 78). Underpinning this study was an interest in the quality of the teachers that raised a question specifically asking about "who are the people that now teach" in schools (p. 78). The concern expressed by the researchers is relevant to the discussion in this paper as it raises a question about the idea of teacher standards and student achievement that is whether a lack of standards amongst teacher is responsible for the drop in student quality. Specifically, is it right to judge "teacher competence" solely based on student's achievement? Is teacher competence an adequate measure of teachers as a professional in the context of the complex nature of education and its human-centered nature?

Therefore, the concern of this paper is situated in the idea that MTS measures teacher's competency by the outcome which is, producing a modal of an ideal person as described in the 
aims of education in Malaysia. The thesis of this paper is that making such an outcome the measure of a teacher's competency or their 'standard" is questionable as to the adequacy and comprehensiveness of the measure of competency. Hence, on this basis the foundation of MTS can be questioned whether it offers a fair measure of teacher performance in Malaysia.

\section{Materials and Methods}

The problem identified in this study related to fairness in the context teaching standards and, some more notable issue that arise, is one that relates to lack of clarity in the concepts used to define standards and quality of teachers. Analytical philosophy is adopted as the approach in this paper because it is designed for looking at specific educational concepts/ideas such as aims, curriculum, and teaching and, in the case of this study, teaching standards and quality.

Since, analytical philosophy lends clarity to the key notions of the complex concept of standards and quality (Archambault, 1965), the approach and it related method helps make MTS as an educational policy on teacher quality more "coherent, justifiable and effective" (McLaughlin, 2000). This is further supported by the argument regarding the '...embeddedness of philosophical considerations in (many) educational policies" (McLaughlin, 2000, p. 444). Consequently, the approach helps the researcher to be reflective and critical (McLaughlin, 2000, p. 444) in my analysis of standards and quality in this paper. It illuminates the problem in MTS, highlighting the issue for policy makers and teacher educators. The findings of the analysis enables suggestions to be made as to what may be done in the context of making clear meaning and understanding of problematic terms such as standards and quality, towards improving educational policy and practice in Malaysia. The suggestions can be applied to other countries where teaching standards are used to measure teacher quality.

Hence, the study begins by applying a considered perspective to the question about teaching standard and quality in MTS and conducting a critical analysis of the notion of standards and quality as well as performance in the context of teachers. In this study, I first consider the philosophical problem of the idea of teacher standards and quality in MTS and analyse the ethical problem of fairness that emerges from my examination (Frankena, 1965, p. 12). I follow this analysis by a critical consideration as to what it tells about teacher standards and quality and hence, how it should be viewed to avoid issues of fairness.

\section{Results}

Based on several relevant studies specifically Goh $(2011,2012)$ that have looked specifically into the issue of teacher quality, performance and standards in MTS, several concerns can be raised directly and indirectly about the implementation of teaching standards. The issues examined were as a result of concerns with the idea of standards in measuring teacher quality, and the move to benchmark teacher quality through achievement of standards. One concern is whether standards are a fair assessment of teacher standard on the basis that it may not offer an adequate account of the nature of teaching and teachers where there is a strong possibility that these aspects may vary according to students. Another related concern is whether standards allow for student diversity, and the need for flexibility in measuring teacher performance in the face of this diversity. A further concern is whether standards is a notion that sits easily in an area such as education that is highly individualized and may not lend itself to an idea of "one size fits 
all".

The idea of standards has its merits but it also has it challenges. Using a checklist to decide whether a teacher is good or not can only be a short term measure. In the long term, standards like any other economic tool can be gotten around. In the end teachers will work to measure and not work for the student. We as teacher educators, policy makers and teachers at heart need to ask what kind of teachers we want to produce and for the teachers themselves or in the case of pre service teachers, what kind of teachers they want to be.

The concerns described above give us some questions to ponder upon with respect to the effectiveness of MTS in improving education in Malaysia.

\section{Discussion}

In implementing teacher standards such as is the case of MTS, it is perhaps important for the parties concerned to ask whether teaching and learning is something that is objective. Is good teaching only about having the right knowledge, understanding, skills and values and able to use them effectively? Although competency is important to teacher quality, it is necessary to ask where the idea of good teaching is situated. Is it situated in teacher's having adequate knowledge, skills and attitudes - competency. Very often, what happens in the classroom cannot be pre-determined. There must be room for flexibility. "A teacher may find it hard to plan a series of steps, as the lesson will be dependent on what her/his students do and say" (Goh, 2011, p.81). Therefore, is it enough to gauge teacher quality on their competency when the outcome cannot be fixed?

Another important point that should be considered is how far teacher quality is reflected in what teachers check off on a checklist. Is this an adequate measure of a teacher and his work? Is it a proper gauge of a good teacher for the teacher themselves and others? A study on teachers in Malaysia found that teachers" "passion and pride in the teaching profession, is really dissolving, albeit slowly yet surely" (Mansor, Fisher, Rasul, Ibrahim, \& Yusoff, 2012). This may be one study and qualitative in nature so it is not generalisable. However, it lends voice to an issue of whether standards are the way forward in a profession where passion, commitment and attitude are equally if not more important to what actually occurs in the classroom.

Therefore, there are benefits and downsides to the use of standards within a framework of adequacy and comprehensiveness of teaching standards such as MTS in improving teacher quality, and hence, the quality of education in a country such as the case of Malaysia. Answers are not provided as I believe it something that must be looked at collectively returning to a proper understanding of education which requires another paper. Suffice to say that this paper takes the perspective that the essence of education lies with the child understood as an individual person and teachers and teaching are there to have a conversation with the child towards where they need to be based on who they and others are as individuals.

In one sense, the formulation and publication of a teacher standard is useful as a guideline for teachers to check on their competency based on the characteristics of a competent teacher as defined by the MOE allowing them in some sense to gauge their performance albeit on their own using the checklist provided. However, in another sense, there are several disadvantages to the standards prescribed by the MOE.

One is that it may be too much to handle, is daunting and demanding for experienced 
teachers much less beginning teachers. Teachers have enough on their plate without being saddled with so many aspects which they themselves may be hard pressed to assess. Additionally, senior/experienced teachers may find it difficult to adopt and adapt to such standards.

Another problem is the idea that teacher's standard or competency is determined by student's achievement is unfair and may not reflect the actual performance or "competency" of a teacher. A child brings with them many "variables" that teacher must work with in the classroom and beyond within the school and their teaching and learning. It is difficult to 'standardize' teachers when students themselves are diverse. Further, to determine their competency and assess them as good, bad or poor teachers solely on this basis is morally questionable.

The disadvantages identified have several implications for teachers and teacher training. In the next section, I highlight several of the more relevant ones.

\section{Implications}

One implication is that pre-service teacher programmes may need to be "standardised" leading to questions about the limited creativity, dynamism and uniqueness of teacher education programmes in universities. A lack of competition among teacher education programmes would mean that students might not be able to get the best programme. This could lead to public and private universities having common programmes which from an social and economic perspective may not be good for the public. We need to ask whether this would best contribute to achieving world class education.

Second, in imposing standards, the role of the leader especially the school heads is important. The nature of their leadership is important. There would need to be standards for them which would include having good leadership ethics.

Third, the school climate is also important if teachers are to achieve what is needed. If the school climate including the school ethos is not appropriate, it is not enough for teachers just to have the competency if it is not supported by the right climate. The basic values of care and justice need to be in place.

Fourth, the implementation of in-service courses is necessary. Indeed the MOE through the Teacher Professional Development Sector are implementing this through Continuous Professional Development (CPD) courses. However, anecdotal evidence obtained through informal discussions with teachers suggest that the standards itself are not adequately being discussed and informed to teachers in schools. Further, the CPD courses that are being carried out are more technical and ignore a very important aspect of developing and addressing the teacher's own ethical stance which is an important standard in the MTS and, also an important basis of teaching and education.

A fifth implication relates to the fact that many factors go into good teaching. One is the social background of the students. It is not enough for the teacher to be competent and meet the standards, if there is no common playing field. Students from rural/urban background, different SES and so on, are all factors that make education complex and not something that is straightforward.

Finally, the characteristics identified in the checklist (as well as the idea of using checklists) to measure standards asks what is obvious. It does not dig deeper into what makes for a 
competent teacher such as in dealing with values issues and dilemma situation and even conflicts in their professional judgment. There are no open-ended questions to measure qualitatively the nature of their competency and how it affects their teaching to help teachers gauge their actual practice.

\section{Conclusion}

In conclusion, it can be said that in measuring teacher competency using an idealistic model of the student is good. However, we need to ask if it is realistic. Is this an adequate judge of a teacher's competency given the concerns and implications outlined in the previous section? Perhaps we need to replace student outcome with some measure that takes into account the nature of teaching, and what it involves so that it is fair. There needs to be a consideration of whether it is fair to take a stand that teachers can actually achieve too ideal without giving adequate consideration to other factors that influence the outcome of teaching by teachers.

In conclusion, policy makers and teacher educators need to re-examine how we ought to measure teacher competency. Perhaps we need to consider whether a competent teacher is one who ticks all the boxes or are they the one who makes a significant difference in the life of his/her students that may or may not be measureable in the immediate.

\section{Acknowledgement}

This paper is an edited version of the plenary speech presented at the 2014 E-Era Conference on The Instructional Profession and Research: Trend and Development on Teacher Education as well as Pre -Service Teachers' Basic Literacy in National Taichung Univeristy of Education 100ctober 2014, Taichung City, Taiwan.

\section{Corresponding Author}

Nur Surayyah Madhubala Abdullah (PHd), Department of Language and Humanities Education, Faculty of Educational Studies, Putra University Malaysia, 43400 Serdang, Selangor.

Email: nsurayyah@upm.edu.my

\section{References}

Archambault, R. D. (Ed.). (1965). Education as Initiation. Philosophical Analysis and Education, 87111.

Asri, S. (2009). SGM jadi peringatan kepada pendidik [MTS to be a reminder to educators]. Harian Metro. Retrieved June 24, 2010 from

Bernama. (2009). Muhyiddin Launches Malaysian Teacher Standard Document. Retrieved October 21, 2019 from

Chapman, K. (2009). Measuring up to new standards. The Star Online. Retrieved October 1, 2010 from

http://thestar.com.my/education/story.asp?file=/2009/6/28/education/4201502\&s ec=education

Frankena, W. K. (1965). Three historical philosophies of education: Aristotle, Kant, Dewey. Scott, Foreman and Co.: Chicago.

Goh, P. S. C. (2011). Improving teacher competence through the new Malaysian Teacher 
Standards: Exploring the challenges for teacher educators. Journal of Research Policy \& Practice of Teachers \& Teacher Education. 1(1), 88- 99.

Goh, P. S. C. (2012). The Malaysian Teacher Standards: A look at the challenges and implications for teacher educators. Educational Research for Policy and Practice. 11, 73-87. https://doi.org/10.1007/s10671-011-9107-8

http://education.bernama.com/index.php?sid=news_content\&id=459375

http://www.nib.com.my/archives/text/view/2937129?pos=1\&hide_header=1\&re sultset=nstpec\%3Awww/crosssearch/search.php\%3A_1310553357\%3Aresultset

Istrate, F. (2018). Impact of Asymmetric Information on the Investment Decision, International Journal of Academic Research in Accounting, Finance and Management Sciences 8 (2): 287-294.

Mansor, A. N., Fisher, L., Rasul, M. S., Ibrahim, M. B., \& Yusoff, N. (2012). Teachers in MalaysiaAre they evolving or dissolving. In The 3rd International Conference on Learner Diversity 18-19 September 2012, Universiti Kebangsaan Malaysia (78-85).

McLaughlin, T. H. (2000). Philosophy and Educational Policy: Possibilities, Tensions and Tasks. Journal of Educational Policy. 15(4), 441-457. 